\title{
ASESSMEN DAN TREATMENT SISWA HIPERAKTIF KB-TK AL BAROKAH MOJOSONGO
}

\author{
Patria Mukti ${ }^{1)}$, Sujoko ${ }^{2)}$, Endang Widyastuti ${ }^{3)}$ \\ Email: patria_mukti@yahoo.com \\ Fakultas Psikologi Universitas Setia Budi Surakarta ${ }^{1,2,3)}$
}

\begin{abstract}
ABSTRAK
Mitra kegiatan PKM ini adalah KB-TK Al Barokah. Kedua mitra ini berada di Mojosongo Surakarta. Permasalahan yang dihadapi mitra yaitu, belum memiliki kemampuan dalam melakukan deteksi dini dan penanganan serta belum memiliki model pembelajaran yang mampu memfasilitasi kebutuhan belajar anak hiperaktif. Tujuan dari program PKM ini adalah untuk membantu mitra dalam memberikan asesmen anak hiperaktif dan mengembangkan model pembelajaran yang tepat untuk anak hiperaktif. Solusi yang diberikan adalah: (a) Memberikan edukasi cara screening deteksi dini anak hiperaktif, (b) Membantu memberikan edukasi treatment untuk anak hiperaktif khususnya dalam kegiatan belajar mengajar.

Setelah diberikan edukasi tentang ADHD, tentang ciri dan karakteristinya serta bagaimana melakukan deteksi dini terhadap ADHD, guru-guru yang ada di KB TK Al Barokah kini sudah memiliki pemahaman yang baik tentang anak ADHD dan sudah mampu melakukan deteksi dini terhadap gangguan ADHD.
\end{abstract}

Kata Kunci: asesmen, hiperaktif, treatment.

\section{PENDAHULUAN}

Manusia membutuhkan pendidikan dalam kehidupannya, pendidikan merupakan usaha agar manusia dapat mengembangkan potensi dirinya melalui proses pembelajaran. Agar proses pembelajaran dapat berjalan dengan baik, maka membutuhkan strategi yang tepat, seperti memaksimalkan modalitas belajar yang dimiliki oleh siswa (sujoko,dkk 2018). Modalitas pada anak ada berbagai macam ada yang positif dan ada pula anak yang mengalami kondisi yang berbeda dalam fisik dan mental. Beberapa anak yang terlahir dengan kelainan fisik dan mental yang disebut juga dengan Special Needs (Anak Berkebutuhan Khusus/ABK). Dengan 
keterbatasan yang dimiliki tidak mampu memperoleh pendidikan secara normal layaknya anak-anak pada umumnya. Untuk itu perlu penanganan secara khusus kepada anak-anak seperti ini.

Salah satu macam Anak Berkebutuhan Khusus (ABK) adalah anak hiperaktif. Menurut Amin (2012) hiperaktif adalah suatu pola perilaku pada seseorang yang menunjukkan sikap tidak mau diam, tidak terkendali, tidak menaruh perhatian dan impulsive (bertindak sekehendak hatinya). Wiguna (2007) mengatakan karakteristik anak hiperaktif adalah (1) tidak bisa duduk diam di dalam kelas, (2) tangan bergerak dengan gelisah, (3) kadang berlari dan naik diatas meja dan memanjat guru, (4) mengalami kesulitan dalam bermain atau kegiatan menyenangkan bersama teman yang memerlukan ketenangan, (5) impulsivitas, mengalami kesulitan dalam menunggu antrian, (6) menjawab sebelum pertanyaan selesai/sering menginterupsi orang lain.

Anak hiperaktif ini membutuhkan penanganan khusus untuk mendapatkan pendidikan agar hak-haknya dapat terpenuhi. Proses pembelajaran untuk hiperaktif tidaklah semudah pada anak normal pada umumnya. Menurut Saptono (2009, dalam Tri, dkk: 2013) bahwa ADHD pada anak mengakibatkan prestasi belajar tidak optimal bahkan pada tingkat prestasi yang rendah dan penampilan psikomotorik buruk, sebagai akibat adanya kesulitan fungsi koordinasi, respon emosi, keterampilan bergaul, dan keterampilan belajar.

Pengetahun guru tentang ADHD menjadi sebuah keharusan bagi guru agar guru agar guru bias melakukan deteksi dan memberikan model pendidikan yang tepat kepada mereka. Menurut Syed dan Husein (dalam Karunia dan Ika, 2016) menjelaskan bahwa Guru memiliki keunggulan dalam melakukan deteksi dini ADHD karena sekolah merupakan tempat dimana ada kontak setiap hari dengan anak yang sama, sehingga gejala ADHD sangat terlihat dan dapat diamati.

Apabila guru dapat mengajarkan dengan metode yang tepat maka pembelajaran akan berubah menjadi pelajaran yang menyenangkan dan pada akhirnya prestasi anak hiperaktif pun dapat meningkat, namun apabila guru tidak memiliki kemampuan dalam mengajar anak hiperaktif maka proses pembelajaran tidak efektif dan cenderung anak hiperaktif akan mencari perhatian atau membuat 
kegaduhan. Anak hiperaktif mempunyai kesulitan dalam memusatkan perhatian belajar (Melinda, 2010). Oleh sebab itu, Guru harus mempunyai kemampuan khusus atau usaha untuk memusatkan perhatian anak khususnya pada anak yang mengalami hiperaktif.

Fenomena seperti diatas sering kita jumpai dan harus dicari solusi untuk dunia pendidikan saat ini, banyak guru yang kurang mengerti bagaimana mendidik anak hiperaktif, pembelajaran yang menarik bagi anak hiperaktif membutuhkan model pembelajaran tersendiri dengan metode khusus dan bantukan alat peraga edukatif (APE) tertentu untuk mendorong anak dalam belajar.

Kasus sebagaimana telah dikemukakan juga ditemukan di KB-TK Al Barokah. Berdasarkan hasil wawancara dengan kepala sekolah dari kedua mitra, disinyalir ada beberapa anak yang terindikasi mengalami hiperaktif. Hal ini didasarkan atas perilaku keseharian anak ketika mengikuti proses belajar mengajar di kelas.

Hal tersebut merupakan tantangan tersendiri bagi pengabdi untuk membantu memberikan solusi dalam memecahkan masalah mitra melalui edukasi terhadap kedua mitra tentang bagaimana mendeteksi gangguan hiperaktif dan penanganannya serta membantu kedua mitra untuk mengembangkan metode pembelajaran yang tepat untuk anak hiperaktif.A nak yang hiperaktif akan cenderung membuat konflik dengan teman-teman lainnya, ia berusaha untuk mencari perhatian dan juga tidak bisa diam. Sehingga anak seperti ini akan mencari aktivitas yang dirasa menarik dan cenderung mengganggu teman lainnya.

Mitra dalam kegiatan PKM ini adalah KB TK Al Barokah. Mitra ini berada di desa Mertoudan Rt 02 Rw IX Kelurahan Mojosongo Kecamatan Jebres Kota Surakarta. KB TK Al Barokah ini belum memiliki kemampuan dalam melakukan deteksi dini dan penanganan serta belum memiliki model pembelajaran yang mampu memfasilitasi kebutuhan belajar anak hiperaktif.

KB-TK ini hanya memiliki guru sebanyak 12 orang dengan siswa sebanyak 121 siswa yang terbagi keberapa kelompok (KB-TK, Play group dan penitipan anak). Dengan jumlah siswa yang begitu banyaknya tentu tidak 
sebanding dengan jumlah guru yang hanya ada 12 orang. Sehingga dengan keterbatasan guru tersebut mengakibatkan guru tidak memiliki waktu yang cukup untuk melakukan asesmen dan treatment untuk anak hiperaktif. Siswa hiperatif tersebut diperlakukan sama dengan siswa-siswa yang lain dan diberi kebebasan dalam belajar. Sehingga siswa yang terindikasi hiperaktif hanya dibiarkan bermain sesuka mereka tanpa ada kontrol yang berarti. Berikut ini adalah gambaran permasalahan yang dihadapi oleh mitra beserta solusi yang akan Tim PKM Tawarkan:

Tabel 1.

Masalah Dan Solusi Yang Ditawarkan Untuk Kedua Mitra

\begin{tabular}{ll}
\hline \multicolumn{1}{c}{ Masalah } & \multicolumn{1}{c}{ Solusi } \\
\hline $\begin{array}{l}\text { Mitra belum memiliki } \\
\text { kemampuan : }\end{array}$ & 1. $\begin{array}{l}\text { Memberikan edukasi / pelatihan kepada guru dalam } \\
\text { melakukan screening deteksi anak hiperaktif }\end{array}$ \\
$\begin{array}{ll}\text { 1. Deteksi dini anak } \\
\text { hiperaktif }\end{array}$ & $\begin{array}{l}\text { 2. } \\
\text { Membantu melakukan edukasi kepada guru tentang } \\
\text { penanganan anak hiperaktif khususnya dalam } \\
\text { 2. Penanganan anak ADHD }\end{array}$ \\
$\begin{array}{l}\text { kegiatan belajar mengajar. } \\
\end{array}$
\end{tabular}

\section{METODE PELAKSANAAN}

Kegiatan pengabdian ini dilakukan dengan dua metode. Metode yang pertama adalah pelatihan asesmen anak hiperaktif yaitu dengan memberikan edukasi deteksi dini anak hiperaktif untuk guru. Edukasi kepada guru ini bertujuan untuk membantu guru dalam melakukan screening anak hiperaktif. Screening deteksi dini ini dilakukan dengan Formulir Deteksi Dini Gangguan Pemusatan Perhatian Dan Hiperaktif (GPPH atau Abbreviater Conners Rating Scale). Alat deteksi dini bisa digunakan kepada anak 36 bulan keatas, alat ini mampu untuk mendeteksi awal adanya gejala gangguan hiperaktif pada anak sehingga sangat membantu untuk guru dalam pengambilan keputusan model pembelajaran yang sesuai. Alat ini bisa digunakan oleh semua siapapun dengan syarat sudah mendapatkan pelatihan sebelumnya oleh ahli, sehingga guru akan mampu menggunakan alat ini. Setelah dilakukan asesment terhadap perilaku anak, maka langkah kedua dalam kegiatan ini adalah dengan memberikan edukasi kepada 
guru tentang penanganan anak hiperaktif khususnya dalam kegiatan belajar mengajar.

Selama kegiatan pengabdian ini berlangsung mitra diharapkan dapat berperan aktif dalam semua proses pengabdian ini. Adapun partisipasi mitra dapat berupa; 1) Menyediakan tempat untuk kegiatan asesmen, treatmen, dan pelaksanaan sharing metode pembelajaran anak hiperaktif, 2) Mengkondisikan guru dan siswa untuk mengikuti rangkaian kegiatan pengabdian, 3) Menjadwalkan dan menyediakan waktu untuk guru dan siswa dalam mengikuti rangkaian kegiatan pengabdian.

\section{HASIL DAN PEMBAHASAN}

Sebelum pelatihan diberikan, Tim dari Fakultas Psikologi Universitas Setia Budi memberikan sedikit quesionare kepada 12 guru yang mengikuti kegiatan ini. Berdasarkan hasil quesionare diketahui bahwa selama ini mereka belum begitu memahami bagaimana mengajar anak ADHD. Berikut ini adalah gambaran bagaimana guru-guru yang ada di KB TK Al barokah mengajar anak ADHD.

\section{Gambar 1}

Gambaran Metode Pembelajaran Yang Selama Ini Dilakukan Untuk Anak ADHD

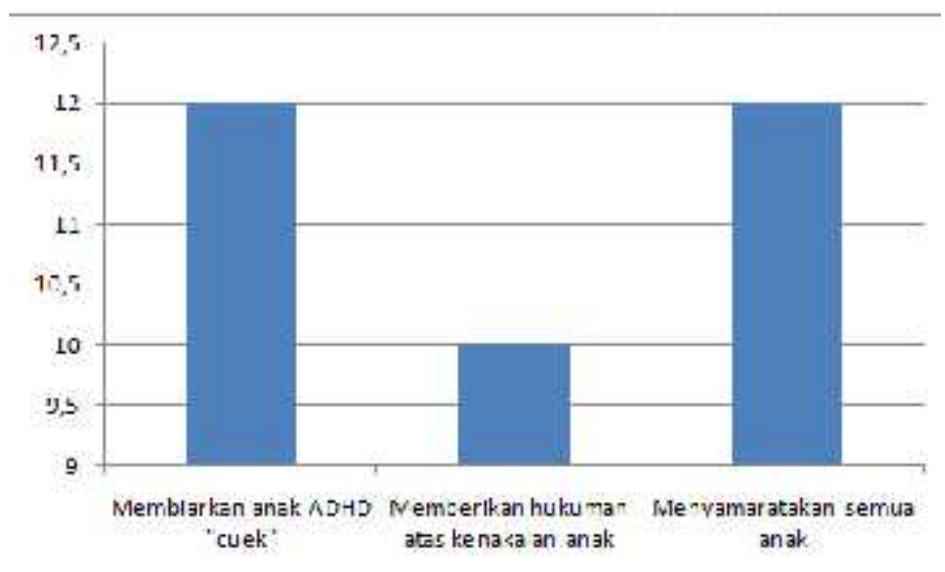

Gambar 1 diatas memberikan gambaran tentang bagaimana selama ini guru KB TK Al Barokah mengajar anak-anak dengan kebutuhan khusus seperti anak ADHD. Tidak ada perlakuan yang berbeda, hampir semua guru (12 guru) memperlakukan anak ADHD dengan perlakuan yang sama. Padahal seharusnya 
anak ADHD mendapatkan perhatian yang lebih dan perhatian yang berbeda karena kekhususan yang ada pada diri mereka. Hal ini disebabkan karena ketidaktahuan para guru tentang bagaimana menangani anak ADHD. Hal ini dikuatkan dengan pengakuan salah satu Guru yang ada di sekolah tersebut, yang menjelaskan bahwa tidak mengerti cara mengajar anak yang mengalami ADHD. Kondisi diatas semakin memotivasi Tim untuk memberikan edukasi kepada para guru yang ada di KB TK tersebut melalui kegiatan pengabdian masyarakat.

Pengabdian ini dibagi menjadi dua sesi yaitu sesi pertama adalah cara mengidentifikasi sejak dini anak yang mengalami ADHD dengan alat tes GPPH (Gangguan Pemusatan Perhatian dan Hiperaktivitas). Alat ini merupakan alat yang bias dipakai bukan hanya dari kalangan psikologi, namun guru TK juga diperbolehkan untuk menggunakan alat GPPH ini dengan syarat telah mendapat pelatihan oleh professional.

Harapan dari tim pengabdi untuk keberlanjutannya setelah pengabdian ini selesai para guru KB-TK Al barokah tetap mampu melakukan asesmen secara mandiri pada anak yang diduga mengalami gangguan ADHD. Sehingga walaupun program dari tim pengabdi sudah selesai namun mereka mampu memakai alat secara mandiri sehingga akan selalu bermanfaat.

Sesi kedua setelah pelatihan deteksi dini dilaksanakan pelatihan untuk menangani anak yang mengalami ADHD, khususnya dalam kegiatan belajar mengajar. Materi mencakup dari persiapan awal sebelum masuk kelas sampai siswa pulang, seperti sebelum memulai pembelajaran siswa diajak kegiatan fisik terlebih dahulu karena anak hiperaktif memiliki tenaga yang luar biasa sehingga sebelum masuk kelas diberi kegiatan seperti senam, lari atau kegiatan lain yang membutuhkan tenaga fisik, di dalam kelas guru harus menempatkan siswa di tempat duduk yang sulit untuk keluar masuk kelas, menjauhkan jarak antar meja, dan juga bekerjasama dengan orang tua agar memberikan perhatian yang lebih kepada anak. Dengan pelatihan penanganan tersebut diharapkan guru di KB-TK Al Barokah mampu untuk menangani siswa yang mengalami ADHD dan mampu memberikan penanganan yang tepat sehingga mampu memberikan pembelajan yang sesuai dengan karakter siswa yang bermacam-macam. 
Berdasarkan hasil evaluasi kuesioner terbuka yang diberikan terhadap 12 guru yang mengikuti kegiatan ini. Terlihat setelah mendapatkan pelatihan, pengetahuan dan pemahaman peserta mengenai pengetahuan dasar anak ADHD, cara deteksi dini dan cara penanganannya mengalami peningkatan. Hal ini dapat dilihat pada diagram dibawah ini:

\section{Gambar 2}

Tingkat pengetahuan Guru tentang ADHD (Pre and post test)

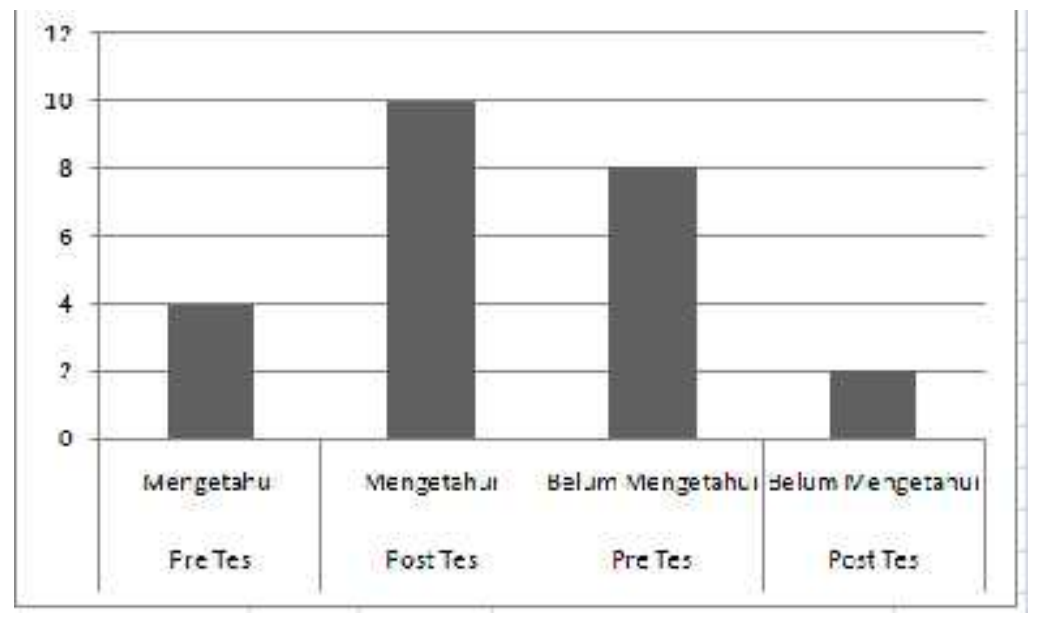

\section{Gambar 3}

Tingkat Pengetahuan Guru Tentang Ciri / Karakteristik Anak Yang ADHD Sebelum Dan Setelah Kegiatan Pengabdian Berlangsung

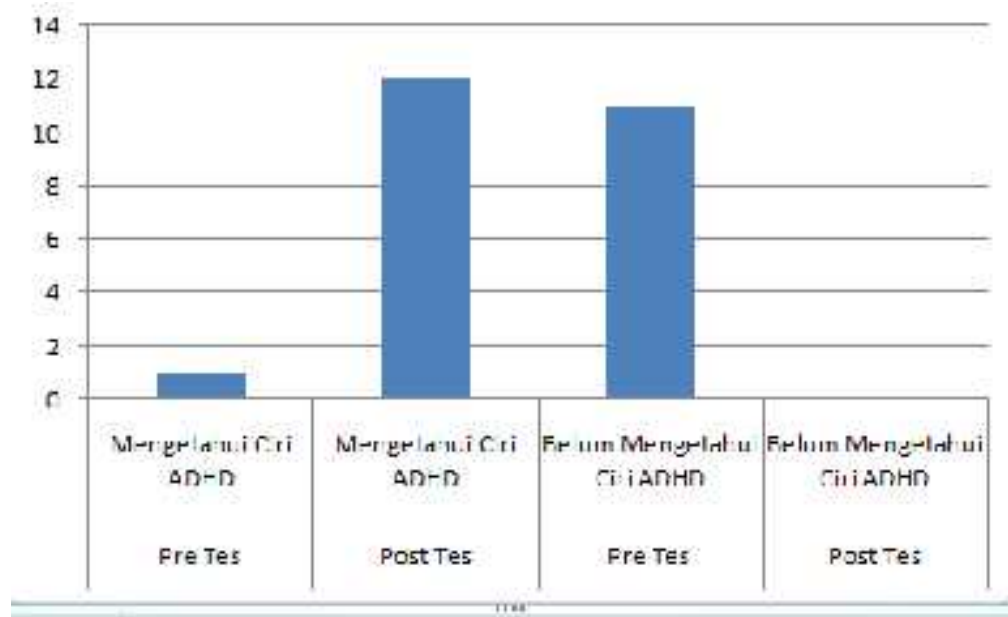

Gambar 4

Empowering: Jurnal Pengabdian Masyarakat Fakultas Psikologi UM Jember | 85 


\section{Kemampuan Guru Dalam Mengidentifikasi Anak ADHD Sebelum Dan Setelah Kegiatan Pengabdian Berlangsung}

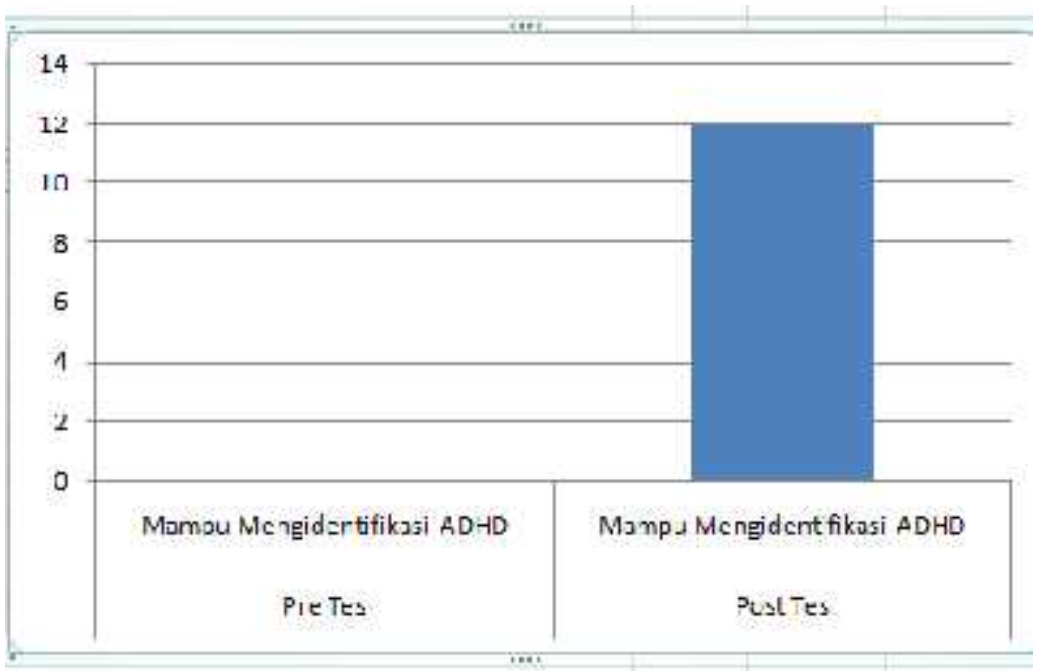

Data-data diatas menunjukkan tingkat keberhasilan dari program pengabdian masyarakat yang dilakukan oleh Tim dari Fakultas Psikologi Universitas Setia Budi Surakarta. Setelah diberikan edukasi tentang ADHD tentang bagaimana melakukan asesmen dan treatment, akhirnya guru-guru yang ada di sekolah tersebut memahaminya dengan baik.

\section{KESIMPULAN DAN SARAN}

\section{Kesimpulan}

Berdasarkan paparan diatas, maka dapat disimpulkan bahwa Identifikasi ADHD perlu dilakukan, karena dengan mengetahuinya dapat membantu guru dalam melakukan penanganan dan menentukan metode pembelajaran yang tepat bagi anak ADHD. Sehingga keberadaan anak ADHD tidak mengganggu anakanak normal lainnya dan proses belajar mengajar dapat berjalan dengan optimal.

\section{Saran}

Berdasarkan temuan-temuan diatas, maka disarankan kepada guru dan pihak sekolah agar dapat memperlakukan anak ADHD dengan perlakuan yang tepat seperti (1) memberikan assessment terlebih dahulu kepada calon peserta 
didik sehingga dapat melakukan pemetaan kecenderungan munculnya perilaku ADHD, (2) berikan kesibukan kepada anak yang terindikasi ADHD sehingga energi yang berlebih dapat tersalurkan dengan baik, (3) tempatkan tempat duduk siswa yang terindikasi ADHD pada posisi yang mudah di observasi dan dijangkau oleh guru, agar anak ADHD dapat berkembang dengan baik dan mampu mengoptimalkan kemampuan yang ada pada mereka.

\section{DAFTAR PUSTAKA}

Amin, Rasmi (2012)."Perilaku Hiperaktif dan Upaya Penanganannya".Diakses darihttp://www.lpmpsulsel.net/v2/index.php?option=com_content\&view=ar ticle\&id=196: hiperaktif\&catid=42: widyaiswara\&Itemid=206. Pada tanggal 7 Juni 2017 pukul 08.52 WIB.

Karunia, Ana, Ika Yuniar Cahyanti (2016) Pengaruh Psikoedukasi tentang Pengetahuan ADHD terhadap Kemampuan Guru dalam Melakukan Deteksi Dini Masalah ADHD pada Siswa dan Keterampilan Intervensi Kelas. JurnalINSAN Vol. 01 No. 01, Juni 2016

Melinda Hospital. 2013. Anak Hiperaktif Penyebab dan Cara Mengatasinya. http://www.melindahospital.com/modul/user/detail_artikel.php?id=1001_A nak-Hiperaktif:-Penyebab-dan-Cara-Mengatasinya

Sujoko, S., Mukti, P., \& Yuniati, R. (2018). Identifikasi Dan Optimalisasi Kecerdasan Siswa (Madrasah Ibtidaiyah Ulumul Qur'an Ali Bin Abi Thalib Mojosongo Surakarta). Empowering: Jurnal Pengabdian Masyarakat, 2, 28-39.

Tri, Ayu Anjani, Najlatun Naqiyah, Sutijono, Hermien Laksmiwati (2013) Studi Kasus Tentang Konsentrasi Belajar Pada Anak Adhd (Attention Deficit Hyperactivity Disorder) Di Sdit At-Taqwa Surabaya Dan Sdn V Babatan Surabaya .Jurnal BK UNESA, Volume 1 Edisi 2, 125-135

Wiguna, T (2007) Gejala, Latar Belakang Permasalahan dan Kebutuhan Anak Dengan Gangguan Pemusatan Perhatian Dan Hiperaktivitas (GPPH) Dan Gangguan Spejtrum Autistik. Makalah Pada Simposium Sehari Kesehatan Jiwa Dalam Rangka menyambut Hari Kesehatan Sedunia, (online). www.idijakbar.com 